II. Aus dem Laboratorium für allgemeine Pathologie zu Bologna, Direktor Prof. Guido Tizzoni.

\section{Weitere Untersuchungen über die Heilung der ausgebrochenen Rabies.}

\section{Von Prof. Guido Tizzoni und Dr. Eugenio Centanni.}

In unseren früheren Arbeiten ${ }^{1}$ ) haben wir ausführlich dargethan, dass das Blut von Kaninchen, welche in so hohem Grade gegen Rabies immun gemacht worden waren, dass sie ohne den geringsten Schaden Inoculationen mit fixem Virus unter die Dura mater ertrugen, nicht nur die Rabies zu verhüten und ihre Entwickelung zu hindern vermag, wenn das Serum desselben in der ersten Zeit der Incubationsperiode eingespritzt wird, sondern auch imstande ist, diese Krankheit in einem vorgerückten Stadium, wenn das ihr eigenthümliche Krankheitsbild schon mehr oder weniger vollständig entwickelt ist, zu heilen.

Schon früher hatte einer von uus zusammen mit Dr. Schwarz, dem damaligen Assistenten dieses Institutes, in einer anderen Arbeit ${ }^{2}$ ), mit welcher die in diesem Laboratorium n̈ber die Immunităt gegen Rabies ausgeführten Untersuchungen ihren Anfang nahmen, versucht, den wirksamen Stoff aus dem Blutserum der gegen Rabies vaccinirten Thiere, wenn auch nicht vollkommen rein, sondern noch mit anderen Albuminoidkörpern gemischt darzustellen, und hatte bewiesen, dass diese Substanz durch Alkohol niedergeschlagen wird, und dass das im Wasser wieder anfoenommene Präcipitat, wenn es in vitro mit der Emulsion des Rückenmarks eines tollen Hundes gemischt wird, dessen Virulenz vollkommen zu vernichten vermag.

Als wir dann die Wirkung dieses alkoholischen Niederschlages gegen das Virus der Rabies am Organismus versuchten, um zu bestimmen, ob sie der des Serums der immunisirten Thiere, von denen das Präcipitat stammte, gleichkåme, erlangten wir in dieser Hinsicht kein positives Resultat, d. h. es gelang uns nicht, mit demselben, wie mit dem Serum, die Thiere von der Rabies zu befreien.

Da jedoch zur Lösung dieser Frage nur ein einziger Versuch gemacht wurde, und da dieser mit Material unternommen wurde, welches von Thieren stammte, die nur einen ersten Grad der Immunisirung erreicht hatten, und deren direkt injicirtes Serum kein constant positives Resultat gab, so können die in dieser Beziehung in der angeführten Arbeit gezogenen Folgerungen nicht als endgültig betrachtet werden.

Darım wollten wir untersuchen, ob man mit Material, welches von in höherem Grade, also gegen das constante Virus immunisirten Thieren stammte, und wie wir es später durch die Vervollkommnung der Vaccinationsmethoden erhalten konnten, zu anderen Folgerungen gelangen konnte.

Das Material zu diesen neuen Untersuchungen wurde Thieren entnommen, welche gegen das fixe Virus immunisirt waren und ein oder mehrere mal der subduralen oder endovenösen Inoculation dieses Virus widerstanden hatten. Das Blut wurde wie gewöhnlich auf vollkonmen aseptische Weise einer starken Arterie entzogen, mit zehn Volumen absoluten Alkohols niedergeschlagen, und der Niederschlag im leeren Raume über Schwefelsäure getrocknet.

Von diesen Thieren batten einige schon Serum zu anderen Experimenten geliefert, man kannte also schon die immunisirende Kraft ihres Blutes und die davon nothige Menge, um ein Thier in einer gewissen Periode der Krankheit von der Hundswuth zu befreien; andere dienten zum ersten male zum Versuch.

Die Probe der stattgefundenen Immunisirung durch Einspritzung des in Wasser gelösten alkoholischen Niederschlags wurde immer, wie bei den in unserer früheren Arbeit angeführten, durch direkte Einspritzung von Serum ausgeführten Versuchen, durch Inoculation von Rabiesvirus von der Strasse in den Nervus ischiadicus bewirkt. Die immunisirenden Injectionen wurden niemals früher, als acht Tage nach der Infection durch jenes Virus ausgeführt.

Wir überzengten uns dadurch, dass das alkoholische Präcipitat, dessen Wirkung wir untersuchten, nicht nur den Organismus gegen das Rabiesvirus schützte, sondern diese immunisirende Wirkung in so hohem Grade besass, dass sie nicht nur zur Verhütung, sondern zur Heilung der Hundswuth dienen konnte, selbst wenn das Virus sich schon auf das Centralnervensystem verbreitet hatte, und die ersten Symptome der Krankheit aufgetreten waren.

Das aus 14-21 ccm des Blutserums erhaltene alkoholische Präcipitat, dessen Gewicht in verschiedenen Experimenten zwischen

l) G. Tizzoni und E. Centanni, Ueber die Art, bei Thieren die schon ausgebrochene Rabies zu heilen. Deutsche med. Wochenschr. No. 271892. - Dieselben, Rendiconti della R. Accad. dei Lincei, seduta del 8. Maggio 1892. - Dieselben, Riforma medica 1892 No. i09.

$\left.{ }^{2}\right)$ G. Tizzoni und B. Schwarz, La profilassi e ia cura della rabbia col sangue degli animali vaccinati contro quella malattia. Rif. med. 1892 No. 18 und 19. - Rendiconti della R. Accad. delle Scienze di Bologra, seduta del 10. Gennaio 1892
0,9 und $1,30 \mathrm{~g}$ schwankte, wurde in fünf bis sechs Dosen, jede von $0,18-0,25 \mathrm{ccm}$ getheilt, welche in wenig sterilisirten Wassers $(1-2 \mathrm{ccm})$ gelöst wurden, wodurch man eine gelbliche, gummöse Flüssigkeit erhielt, welche sogleich nach der Zubereitung in das Unterhautbindegewebe des zu heilenden Thieres eingespritzt wurde.

Hier folgen ohne weiteres die Protokolle unserer Experimente.

Experiment 1. Das Thier wird am 20. Mai 1892 inficirt, und die Behandlung beginnt am neunten Tage nach der Inoculation. Das Material wird zubereitet indem man zwei gegen das fixe Virus immunisirten Thieren Blut entzieht, und das von beiden erhaltene Serum vermischt. Von der ganzen, $42 \mathrm{~cm}$ betragenden Menge wird die Hälfte mit Alkohol niedergeschlagen, die anđere Hälfte einem Controllkaninchen beigebracht. Die trockene Substanz wiegt $1,20 \mathrm{~g}$; sie wird in sechs Theile getheilt, welche einmal täglich während sechs auf einander folgender Tage, also bis zum 15. Tage nach der Infection, injicirt werden. Die aufgetretenen Symptome gehen infolge der Behandlung schnell zurück, und das Thier lebt noch jetzt in bester Gesundheit 80 Tage nach der Infection.

Auch das Thier, welches zugleich mit diesem mit gleichwerthigen Dosen von Serum behandelt wurde, zeigte nach diesen Injectionen kein Symptom der Rabies mehr und lebt noch gegenwärtig.

Ein drittes Thier, welches mit den beiden obigen der Controlle wegen zugleich inficirt worden war, starb am 18. Tage an Rabies.

Experiment 2. Das Thier wird am 7. Juni 1892 inficirt. Die Behand lung beginnt am neunten Tage der Krankheit und dauert fünf Tage lang, wobei im ganzen $1 \mathrm{~g}$ des alkoholischen Niederschlags verbraucht wird, welchen man aus $20 \mathrm{ccm}$ des Serums eines immunisirten Thieres gewonnen hatte. Seit dieser Behandlung, 70 Tage nach der Infection, hat dieses Thier niemals krankhafte Symptome dargeboten. Das Controllthier starb am 19. Tage.

Experiment 3 . Die Infection findet am 24. Juni 1892 statt. Die Behandlung beginnt am Anfange des achten Tages nach der Infection, wozu im ganzen $1,3 \mathrm{~g}$ des alkoholischen Präcipitats, aus $17 \mathrm{ccm}$ Serum von einem immunen Thiere stammend, in fünf Dosen getheilt in fünf auf einander folgenden Tagen verbraucht wurden. Auch dieses Thier lebt heute noch, 60 Tage nach der Infection. Das Controllthier starb am 20. Tage.

Experiment 4. Das Thier wird am 27. Juni 1892 inficirt, und die Behandlung beginnt erst am achten Tage der Krankheit. Es erhält $0,9 \mathrm{~g}$ alkoholischen Präcipitats, aus $14 \mathrm{ccm}$ von dem Serum eines immunisirten Thieres stammend, in fünf täglichen Dosen. Das Thier erfreut sich noch bester Gesundheit, 60 Tage nach der Infection. Das Controllthier starb am 20. Tage.

Diesen unseren Experimenten haben wir nicht für zweckmässig gefunden, noch weitere hinzuzufügen, theils um an kostbarem Material zu sparen, theils weil ihre Zahl, besonders in Hinsicht auf die Qualität der Infection, welche in ihrer experimentellen Entwickelung nur sehr seltene Ausnahmen darbietet, und auf die sichere Weise, mit welcher dieselbe hervorgerufen wurde, mehr als hinreichend scheinen muss, um ein Urtheil zu gewinnen.

Um unser Urtheil abzugeben, haben wir es also nicht für nöthig gehalten, zu warten, bis nach unseren Experimenten noch längere Zeit verflossen wäre. Dies kann nöthig sein, um sich über präservative Einspritzungen eine Meinung zu bilden, besonders wenn dieselben mit einem Serum oder dessen Producten gemacht wurden, welche von Thieren stammen, die sich auf der ersten Stufe der Immunität befinden, welche in geringer Menge, ohne das inoculirte Virus ganz zu zerstören, keine andere Wirkung hervorbringen können, als die Verlängerung der Incubationsperiode der Krankheit, auf dieselbe Weise, áls wenn von diesem Virus nur sehr geringe Mengen inoculirt worden wären. Anders ist es, wenn die Behandlung der Krankheit beginnt, wenn dieselbe sich schon entwickelt hat, und man sehr kräftiges Serum anwendet.

In der That begreift man leicht, dass, wenn es in diesem letzten Falle gelingt, eiuige Wirkung zu erzielen, und noch vielmehr, wenn man das Thier zu retten vermag, man dies nur unter der Bedingung erreichen kann, dass man sich eines hinlänglich kräftigen Stoffes bedient, um grosse Massen von Virus, alles was sich im Nervensysteme dieser Thiere bis dahin angehäuft hatte, zu zerstören.

Ueberdies ist nach unseren beiden ersten Experimenten schon Zeit genug verflossen, um ein sicheres Urtheil fällen zn können; alle ohne Unterschied haben schon längst die Zeit überschritten, wo die respectiven Controllthiere ohne Ausnahme sterben mussten.

Die hier beschriebenen Untersuchungen führen also bei der Rabies zu denselben Schlüssen, zu denen wir schon beim Tetanus gelangt sind ${ }^{1}$, dass man nämlich durch Niederschlagung mit Alkohol neben anderen Albuminoidkörpern den wirksamen Stoff aus dem Blutserum der gegen diese Krankheit vaccinirten Thiere in fester Gestalt erhalten kann, und dass dieser Niederschlag, wieder in Wasser gelöst, das Blutserum, welchem es entstammt, sehr wohl ersetzen kann, sowohl in seiner Wirkung in vitro auf das Rabiesvirus, als in der Wirkung auf ein wuthkrankes Thier.

Dass aber der alkoholische Niederschlag in demselben Grade wirksam bleibt, wie das Blutserum, wird deutlich genug durch

I) G. Tizzoni und G. Cattani, Sulle proprietà dell' antitossina del tetano. Rif. med. 1891 No. 102. - Rendiconto della R. Accad. dei Lincei, seduta del 5. Aprile 1891. 
unser Experiment 1 bewiesen, wo wir an zwei Thieren unter denselben Verhältnissen experimentirten und durch das alkoholische Präcipitat dieselbe Heilwirkung erzielten, wie durch eine Serummenge gleich derjenigen, aus welcher das Präcipitat abgeschieden worden war.

Dies ist gewiss eine Thatsache von nicht geringer wissenschaftlicher und praktischer Wichtigkeit. Sie bestätigt nicht nur unsere früheren Untersuchungen über die Heilung der schon entwickelten Rabies, sondern lässt uns auch eine von den Eigenschaften jener Substanz vaccinirter Thiere erkennen, welche dem Virus der Hundswuth entgegenwirkt, und macht es ausserdem möglich, diese Substanz in einer Form zu erhalten, in welcher sie sich für unbestimmte Zeit unverändert aufbewahren lässt.

So haben wir die Mittel erlangt, nach und nach von vaccinirten Thieren die wirksame Substanz ihres Serums zu sammeln, bis wir die Mengen anhäufen, welche zu Versuchen am Menschen nöthig sind, sie immer zu diesem Zwecke bereitzuhalten, und zwar in einer Form, welche ihren Gebrauch und ihre Versendung erleichtert. Dies kann man den ersten Schritt zur Benutzung des Blutserums gegen Rabies vaccinirter Thiere bei der Behandlung des Menschen nennen, oder vielmehr zum Gebrauche jener Substanz, welcher das Blutserum seine immunisirenden und heilenden Eigenschaften verdankt.

Was die Minimaldose des alkoholischen Niederschlages betrifft, welche zur Heilung eines von Rabies ergriffenen Kaninchens nöthig ist, so können wir uns nicht auf absolute Weise aussprechen. Es ist nicht unmöglich, dass wir, um beständig positive Resultate zu erhalten, stärkere Dosen angewendet haben, als nöthig gewesen wäre, und dass viel geringere Dosen des Präcipitats die gewünschte Wirkung ebenfalls hervorgebracht haben würden.

Wir glaubten auch nicht, diesem Punkte näher treten zu sollen, denn wenn auch für das Kaninchen die Minimaldose des alkoholischen Niederschlages festgestellt würde, welche genügt, um bei ihm die schon zum Ausbruch gekommene Rabies zu heilen, so hätten wir doch diesen Befund nicht direkt nach einer einfachen Verhältnissréchnung auf den Menschen anwenden können, ohne der verschiedenen Empfänglichkeit des Menschen für diese Krankheit, der verschiedenen Kraft des Virus und vielen anderen Dingen Rechnung zu tragen, und es ist unmöglich, diese Kenntniss anders zu erlangen, als durch direkte Versuche am Menschen selbst. 